\title{
Komunikasi Pembangunan Pemerintah Desa Aikmual Kecamatan Praya dalam Mengatasi Pengangguran Melalui Pelatihan Las
}

\author{
Lalu Wire Panggih¹, Yulanda Trisula Sidarta Yohanes², Lalu Ahmat Rahmat ${ }^{3}$ \\ 1,2,3 Universitas 45 Mataram, Kota Mataram, Indonesia \\ Contact: landak.landa@gmail.com
}

\begin{abstract}
The background of this research was Central Lombok experienced a decrease in unemployment, namely $2.44 \%$. This reduction in the unemployment rate by the Village Government of Aikmual, Praya District can be overcome by welding training to village youth. It was made researcher known to find out the development communication carried out by the Aikmual Village Government in implementation of welding training. This is what makes researchers know to find out the development communication carried out by the Aikmual Village Government in implementing welding training. This type of research is qualitative with data collection techniques through interviews and documentation. The result of the research is that the implementation of development communication by the Aikmual Village Government applies four aspects, namely strength of the capacity of village youth, fairly and openly to the village youths to participate in activities, implementing controls empowerment through monitoring, and this activity is sustainable. The development, communication process in developing local communities involves aspects of the village government as a communicator or executor in program implementation, delivering development materials (training material), village youth as communicants, and the effects that village youths have after participating in treatment.
\end{abstract}

Keywords: development communication, unemployment, village government

\begin{abstract}
ABSTRAK
Latar belakang penelitian ini adalah Lombok Tengah mengalami penurunan angka pengangguran, yaitu 2,44\%. Penurunan angka pengangguran ini oleh Pemerintah Desa Aikmual Kecamatan Praya dapat diatasi melalui pemberian pelatihan las kepada pemuda desa. Hal ini yang membuat peneliti untuk mengetahui untuk mengetahui komunikasi pembangunan yang dilakukan Pemerintah Desa Aikmual dalam pelaksanaan pelatihan las. Jenis Penelitian ini adalah kualitatif dengan teknik pengumpulan data melalui wawancara dan dokumentasi. Hasil penelitian adalah pelaksanaan komunikasi pembangunan Pemerintah Desa Aikmual menerapkan empta aspek, yaitu penguatan kapasitas pemuda desa, pemerintah desa bertindak adil dan terbuka kepada pemuda desa untuk mengikuti kegiatan, pelaksanaan pemberdayaan yang terkontrol melalui monitoring, serta kegiatan ini berkelanjutan. Proses komunikasi pembangunan dalam mengembangkan masyarakat lokal melibatkan aspek pemerintah desa sebagai komunikator atau eksekutor dalam pelaksanaan program, menyampaikan materi pembangunan (materi-materi pelatihan), pemuda desa sebagai komunikan, serta efek yang diperoleh pemuda desa setelah mengikuti pelatihan.
\end{abstract}

Kata Kunci : Komunikasi Pembangunan, Pengangguran, Pemerintah Desa

\section{Pendahuluan}

Pengangguran merupakan ancaman bagi setiap daerah apabila pemerintah setempat tidak peduli terhadap kondisi perekonomian masyarakat setempat. Pengangguran terjadi karena adanya ketidakcocokan antara penawaran tenaga kerja dengan permintaan tenaga kerja. Ini artinya jumlah permintaan kerja yang sedikit dibanding dengan penawaran kerja yang 
meningkat. Apabila masalah pengangguran tidak segera teratasi, yang terjadi adalah akan menambah angka kemiskinan.

Lombok Tengah merupakan salah satu kabupaten yang berada di Provinsi Nusa Tenggara Barat yang mengalami permasalahan pengangguran. Angka pengangguran di Kabupaten Lombok Tengah mengalami penurunan sejak tahun 2018-2019. Menurut Syamsudin, Kepala BPS Lombok Tengah dalam wawancaranya dengan radarmandalika.id (2020) menjelaskan bahwa terjadi penurunan angka pengangguran dari tahun 2018 sampai dengan 2019 data terakhir. Pada tahun 2018, angka pengangguran tercatat 3,08\%, sedangkan pada tahun 2019 angka pengangguran tercatat 2,44\%.

Pengurangan angka pengangguran dapat dilakukan oleh pemerintah setempat untuk melaksanakan kegiatan yang menunjang hard skill maupun soft skill bagi masyarakat. Hal tersebut dilakukan oleh Pemerintah Desa Aikmual Kabupaten Lombok Tengah dalam mengatasi pengangguran melalui kegiatan pelatihan las bagi pemuda desa. Pemerintah Desa Aikmual melakukan kegiatan pelatihan las ini untuk membangun sumber daya manusia dan mengembangkan kreativitas pemuda Desa Aikmual dalam menunjang hard skill.

Pemerintah Desa Aikmual menjalankan fungsinya dalam pembangunan masyarakat. Dalam menjalankan pembangunan tersebut, membutuhkan komunikasi yang sinergi antara pemerintah Desa Aikmual dengan pemuda setempat. Komunikasi tersebut dilakukan untuk menyamakan persepsi antara pemerintah desa dengan pemuda setempat dalam menjalankan kegiatan pelatihan las. Komunikasi yang dilakukan oleh pemerintah desa aikmual ini menjadi terobosan dalam melatih hard skill pemuda desa dalam penguatan kapasitas untuk memiliki kemampuan atau keahlian di bidang las apabila pemuda desa membuka lahan pekerjaan sendiri. Oleh karena itu, pelatihan ini menjadi program awal dari beberapa program kelanjutan pemerintah desa dalam membekali pemuda Desa Aikmual untuk bisa secara mandiri nantinya dalam mengelola usaha. Hal tersebut merupakan dasar dalam penelitian ini, dimana penelitian ini bertujuan untuk mengetahui komunikasi pembangunan yang dilakukan Pemerintah Desa Aikmual dalam pelaksanaan pelatihan las.

Pelaksanaan kegiatan komunikasi tidak lepas dari tujuan komunikasi itu sendiri. Mengutip dari Effendi (2009:8) dalam bukunya yang berjudul "Dimensi-Dimensi Komunikasi" adalah sebagai berikut: (1). Perubahan sosial/aprtisipasi sosial, yaitu memberikan berbagai informasi pada masyarakat dengan tujuan akhir supaya masyarakat mau mendukung dan ikut serta terhadap tujuan informasi itu disampaikan; (2). Perubahan sikap, yaitu kegiatan memberikan berbagai informasi pada masyarakat dengan tujuan supaya masyarakat akan berubah sikapnya; (3). Perubahan opini, yaitu memberikan berbagai informasi kepada masyarakat dengan tujuan akhir supaya masyarakat mau berubah pendapat dan persepsi; (4). Perubahan perilaku, yaitu kegiatan memberikan berbagai informasi pada masyarakat dengan tujuan supaya masyarakat akan berubah perilakunya.

Tujuan komunikasi yang diuraikan di atas senada dengan konsep komunikasi pembangunan yang didefinisikan oleh Effendy. Menurut Effendi (2006:92) dalam penelitian Mahmud (2007) menjelaskan komunikasi pembangunan merupakan proses penyebaran pesan oleh seseorang atau sekelompok orang kepada khalayak guna mengubah sikap, pendapat, dan 
perilakunya dalam rangka meningkatkan kemajuan lahiriah dan kepuasan batiniah. Yang menjadi benang merah disini adalah tujuan komunikasi dalam pembangunan ini menitikberatkan pada perubahan yang diinginkan oleh komunikator kepada komunikan (yaitu sikap, perilaku, serta pendapat masyarakat).

Pemerintah desa dalam menjalankan komunikasi pembangunan di wilayahnya membutuhkan perencanaan yang sesuai dengan kebutuhan masyarakat. Dalam mempersiapkan komunikasi kepada masyarakat, maka dibutuhkan komponen yang bisa mendukung agar komunikasi yang dilakukan oleh pemerintah desa dapat berjalan dengan lancar. Komponen-komponen komunikasi menurut Laswell menguraikan sebagai berikut: (1). Who; (2). Says what; (3). In which channel; (4). To whom; (5). With what effect. Komponenkomponen tersebut dapat bermanfaat ketika pemerintah desa telah menentukan siapa yang akan menjadi komunikator untuk menyampaikan pesan kepada pemuda desa (komunikan), sehingga pesan yang telah tersampaikan tersebut menimbulkan efek yang dapat mengubah sikap, perilaku, serta opini pemuda desa.

Pelaksanaan komunikasi pembangunan yang mengutamakan penguatan kapasitas sumber daya manusia memiliki empat aspek yang ada dalam pembangunan kualitas manusia menurut Sutaryo (2005:279) menguraikan sebagai berikut:

(1). kapasitas (capacity) pembangunan harus mencakup pengembangan kapasitas, kepada apa yang harus dilakukan orang untuk meningkatkan kemampuan dan menentukan masa depannya; (2). Keadilan (equity), pembangunan harus menekankan pada pemerataan dan dapat dinikmati oleh seluruh lapisan masyarakat. Perhatian yang tidak merata pada berbagai kelompok masyarakat, dapat memecah belah masyarakat dan menghancurkan serta melemahkan kemampuan mereka; (3). Pemberdayaan (empowerment), pembangunan mengandung arti pemberian kuasa dan wewenang yang lebih besar kepada masyarakat bila mereka memiliki wewenang yang sepadan (masyarakat lemah); (4). Berkelanjutan (sustainable), pembangunan tidak hanya berhenti disitu saja, karena pembangunan bersifat continue, pembangunan harus diperhatikan, dipantau demi kelangsungan masa depan.

Pembangunan kualitas sumber daya manusia membutuhkan kerja sama yang sinergi antara pemerintah desa dengan masyarakat setempat. Hal ini membutuhkan pencarian informasi yang detail mengenai kebutuhan masyarakat. Untuk mengetahui informasi dari masyarakat, ada beberapa model yang dikemukakan oleh Jack Rothman dalam Suharto (2007) yang dikutip dalam artikel Gunadi (2012) adalah sebagai berikut:

"pengembangan masyarakat lokal (locality development), perencanaan soial (social planning) dan aksi sosial (social action). Ketiga model tersebut saling berpengaruh satu sama lain, setiap komponennya dapat digunakan sesuai dengan kebutuhan dan situasi yang ada di masyarakat. Ketiga model tersebut dapat dijelaskan yaitu: a) Pengembangan masyarakat lokal, adalah proses yang ditujukan untuk menciptakan kemajuan sosial dan ekonomi bagi masyarakat, melalui partisipasi aktif dan inisiatif anggota masyarakat itu sendiri. Pengembangan masyarakat lokal lebih berorientasi 
pada tujuan proses daripada tujuan hasil atau tugas. Maksudnya setiap anggota masyarakat bertanggung jawab untuk menentukan tujuan dan memilih strategi yang tepat dalam mencapai tujuan tersebut. Pengembangan kepemimpinan lokal, peningkatan informasi, komunikasi, peningkatan startegi, relasi dan keterlibatan anggota masyarakat merupakan inti dari proses pengembangan masyarakat lokal yang bernuansa bottom up. b) Perencanaan sosial, menunjuk pada proses pragmatis untuk menentukan keputusan dan menetapkan tindakan dalam memecahkan masalah sosial tertentu seperti anak terlantar, kenakalan remaja, kemiskinan dan kesehatan masyarakat. Berbeda dengan pengembangan masyarakat lokal, perencanaan sosial lebih beorientasi pada tujuan hasil atau tugas. Pekerja sosial berperan sebagai perencan sosial yang memandang klien sebagai konsumen atau penerima pelayanan. Keterlibatan para penerima pelayanan dalam proses pembuatan kebijakan, penentuan tujuan dan pemecahan masalah bukan merupakan prioritas, karena pengambilan keputusan yang dilakukan oleh para pekerja sosial di lembaga formal. c). Aksi sosial, pendekatan aksi sosial ini didasari suatu pandangan masyarakat merupakan sistem klien yang sering terjadi sebagai korban ketidakadlian struktur, maksudnya mereka miskin karena dimiskinkan, mereka tidak diberdayakan dan mereka lemah karena dilemahkan, oleh kelompok elit masyarakat yang meguasai sumber-sumber ekonomi, politik dan kemayarakatan. Aksi sosial berorientasi pada tujuan proses dan hail. Masyarakat diorganisisr melalaui prose penyadaran, pemberdayaan dan tindakan-tindakan aktual untuk mengubah struktur kekuasaan agar lebih memenuhi prinsip demokrasi, kemerataan dan keadilan."

Implementasi komunikasi pembangunan membutuhkan sebuah proses. Proses komunikasi pembangunan menurut Dilla (2007) melibatkan minimal tiga komponen, yaitu komunikator, pesan, dan komunikan. Komunikator dalam komunikasi pembangunan dapat berasal dari pemerintah ataupun dari pihak masyarakat yang bertujuan pembangunan. Pesan dalam hal ini adalah ide atau gagasan yang tertuang dalam program pembangunan, sedangkan komunikan adalah yang menerima pesan tersebut, yaitu masyarakat secara luas. Dengan demikian proses komunikasi, antara pemerintahan dengan masyarakat untuk menemukan materi melalui ide, gagasan maupun inovasi sebagai tujuan akhir dalam komunikasi pembangunan. Proses komunikasi pembangunan dapat digambarkan melalui bagan berikut di bawah ini: 


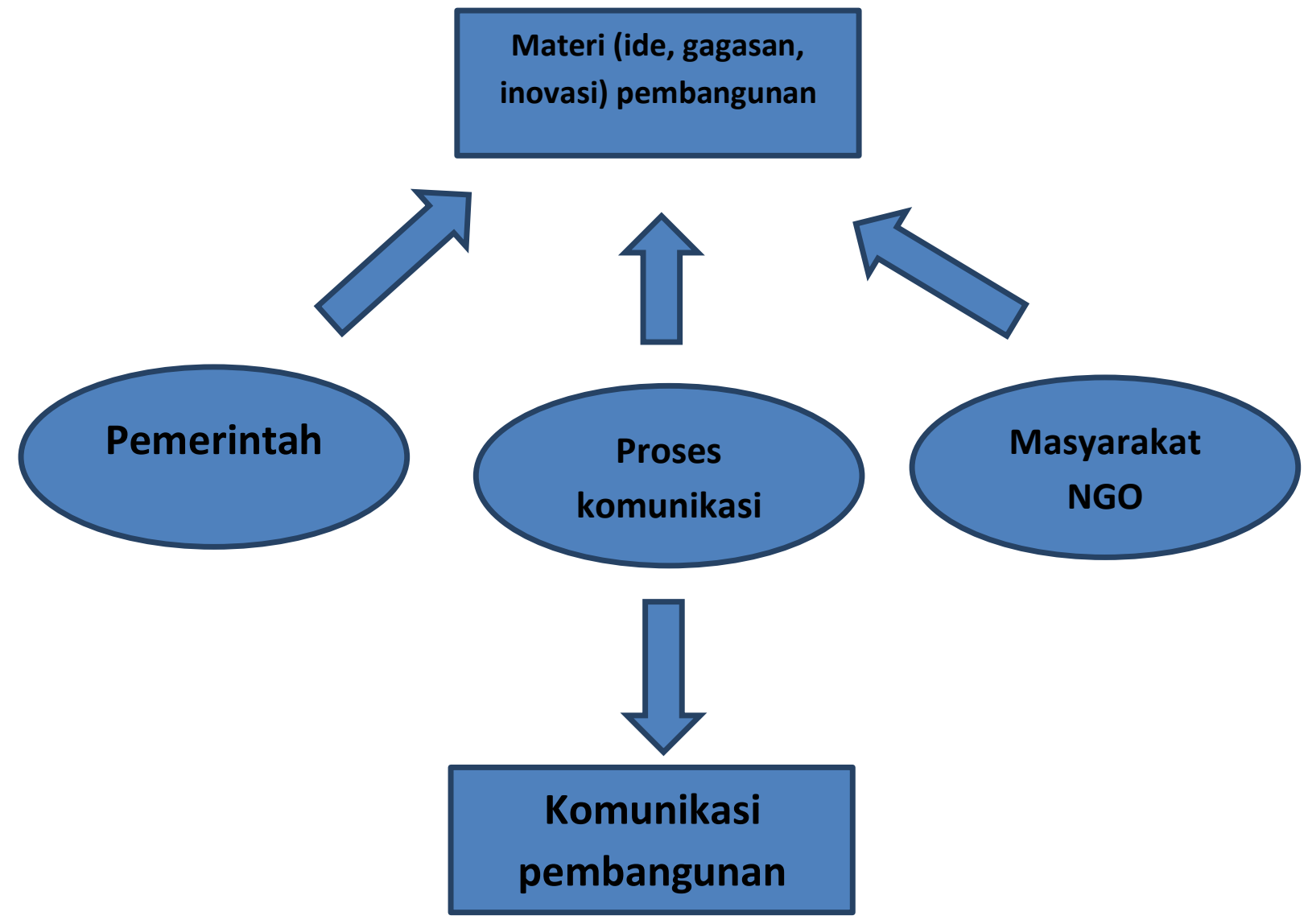

Bagan 1. Proses Komunikasi Pembangunan

(sumber: Dilla, 2007: 120)

\section{Metode}

Penelitian ini adalah penelitian kualitatif dengan sifat deskriptif. Menurut Kriyantono (2008:56) penelitian kualitatif merupakan penelitian yang bertujuan untuk menjelaskan suatu fenomena sedalam-dalamnya melalui pengumpulan data yang sedalam-dalamnya, dengan demikian tidak terlalu mengutamakan besarnya populasi atau sampling. Peneliti menjelaskan komunikasi pembangunan yang dilakukan oleh Pemerintah Desa Aikmual Lombok Tengah dalam mengatasi pengangguran melalui kegiatan pelatihan las.

Teknik pengumpulan data pada penelitian ini terdiri dari wawancara dan dokumentasi. Teknik wawancara merupakan cara pengumpulan data atau informasi dengan cara bertatap muka langsung yang akan dilakukan dengan informan yang sudah ditentukan dengan maksud mendapatkan gambaran lengkap tentang topik yang diteliti (Kriyantono: 2008:100). Informan yang diwawancarai peneliti ini adalah sebagai berikut: (1). Kepala Desa (Muhammad Hasyim), (2). Kasi Kesra (Aisyah Zaini M.); (3). Kaur Perencanaan (Muhammad Syarifudin); dan (4). Ketua Kelompok Pemuda Yayan Suparlan.

Dokumentasi merupakan pengumpulan data yang dilakukan pada berbagai dokumen baik yang bersifat pribadi maupun umum antara lain terdiri dari foto-foto, berbagai bentuk catatan tertulis, studi kepustakaan, dan sampai kepada berbagai sumber resmi dokumen 
pemerintah (Faturrahman, 2016:81). dokumen yang dikumpulkan peneliti adalah kumpulan foto yang diperoleh peneliti melalui arsip yang dimiliki oleh Kantor Desa Aikmual Lombok Tengah.

\section{Hasil dan Pembahasan}

Berdasarkan hasil penelitian yang peneliti peroleh dari wawancara dengan informan dan pengumpulan dokumentasi, maka dapat diperoleh bahwa pelaksanaan kegiatan pelatihan las yang menjadi program kerja Pemerintah Desa Aikmual Kabupaten Lombok Tengah menjadi terobosan yang bisa menghasilkan dalam penguatan kapasitas pemuda untuk mengambil peran dalam ikut serta mendapatkan pengetahuan kegiatan tersebut. Hal ini dapat dibuktikan berdasarkan hasil wawancara dengan Rasyid Rido (Kasi Pemerintahan) yang menjelaskan bahwa:

"Warga pemuda pengangguran sangat antusias dengan program
pemberdayaan ini, dimana program tersebut sangat bermanfaat dirasakan
oleh mereka, manfaat yang dirasakan adalah mereka para pemuda
pengangguran memiliki keterampilan baru dan memiliki nilai jual yang
tinggi yang dapat membantu keluarga." (Hasil Wawancara dengan Rasyid Rido, tanggal 05 agustus 2020, Pkl. 17:47 WITA )

Antusias pemuda Desa Aikmual yang disampaikan oleh Kasi Pemerintahan di atas juga didukung oleh pernyataan Kasi Kesejahteraan Masyarakat, yaitu Aisyah Zaini M yang menyampaikan sebagai berikut:

“...Alhamdulillah kami selaku Kasi Kesejahteraan Rakyat (Kesra) merasa bersukur atas adanya terbukaan Desa kami dalam penyampaian informasi kegiatan apalagi terkait pengembangan kesejateraan rakyat, ini mendukung potensi rakyat dalam pelatihan las. Namun tidak jauh dari informasi datang dari pemerintah Desa yang sistem informasi yang disampaikan tidak pandang bulu dan keterbukaan informasi mengikuti struktur pemerintah Desa dari RT/WR, Kepala Dusun, dan Karang Taruna." (Hasil Wawancara dengan Aisyah Zaini M, tanggal 13 Agustus 2020, Pkl. 09.33 WITA).

Peneliti menganalisa berdasarkan teori yang dikekukakan oleh Effendi (2009:8) bahwa kegiatan yang dilakukan oleh pemerintah Desa Aikmual memberikan dampak dalam partisipasi sosial, dimana pemuda Desa Aikmual Kecamatan Praya Lombok Tengah mendukung kegiatan, serta ada perubahan perilaku yang diberikan pemuda desa terhadap kegiatan tersebut, yaitu pemuda Desa Aikmual antusias untuk mendapatkan wawasan baru yang dapat menunjang hard skill yang dapat menambah keahlian untuk bisa mengoperasionalkan alat-alat las, sehingga dari kemampuan tersebut pemuda Desa Aikmual dapat mengaplikasikannya sendiri untuk membuka usaha.

Pemerintah Desa Aikmual Kecamatan Praya sebagai komunikator mampu mneyabarkan informasi yang dibutuhkan oleh pemuda desa. Informasi tentang pelatihan las ini menjadi pesan yang bisa diterima oleh pemuda desa yang kemudian mendapatkan respon 
atau feedback positif oleh pemuda tersebut. Hal ini menunjukkan bahwa keterbukaan informasi yang diberikan oleh Pemerintah Desa Aikmual Kecamatan Praya dapat memberikan dampak perubahan sikap pemuda desa, yaitu mau mengikuti pelatihan tersebut. Pemerintah desa dalam menyampaikan informasi berupaya untuk mengkomunikasikan pembangunan yang ada di desa tersebut, supaya pemuda yang belum mendapatkan pekerjaan (pengangguran) memiliki kemampuan yang dapat menjadi bekal untuk mereka di akan datang.

Proses komunikasi pembangunan yang dilakukan oleh pemerintah Desa Aikmual Kecamatan Praya merupakan sinergi dengan harapan pemuda Desa Aikmual. Hal tersebut berdasarkan hasil wawancara dengan Kepala Desa Aikmual sebagai berikut:

“...selaku kepala pemerintah Desa, kami selalu melakukan komunikasi dan ikhtiar dengan baik kepada seluruh warga yang ada di wilayah kami. Hal ini kami lakukan tidak ada lain kecuali menjalankan amanah sesuai dengan tupoksi yaitu pembinaan kemasyarakatan, seperti pelaksanaan hak dan kewajiban masyarakat, partisipasi masyarakat, sosial budaya masyarakat, keagamaan, dan ketenagakerjaan, dan pemberdayaan masyarakat, seperti tugas sosialisasi dan motivasi masyarakat di bidang budaya, ekonomi, politik, lingkungan hidup, pemberdayaan keluarga, pemuda, olahraga, dan karang taruna. Serta menjaga hubungan kemitraan dengan lembaga masyarakat dan lembaga lainnya "

(Hasil Wawancara dengan Kepala Desa Muhammad Hasyim, Kamis, 13 Agustus 2020, Pkl. 11.17 WITA)".

Keterbukaan informasi oleh pemerintah setempat menjadi pembuka jalan bagi desa tersebut dalam menjalankan komunikasi pembangunan yang fokus pada penguatan sumber daya manusia melalui kegiatan pemberdayaan masyarakat. Oleh pemerintah desa, kegiatan tersebut ditindaklanjuti untuk segera dilakukan supaya informasi dapat tersampaikan ke pemuda desa dan segera dilaksanakan. Pelaksanaan kegiatan tersebut memerlukan penyamaan persepsi dengan warga yang menjadi target sasaran (pemuda desa) untuk mendapatkan sosialisasi mengenai kegiatan pelatihan las. Oleh karena itu, pemerintah setempat perlu merencanakan sosialisasi yang akan dilakukan. Hal tersebut terdapat dalam hasil wawancara dengan Kaur Perencanaan sebagai berikut:

“...Rasa syukur dan berterima kasih atas adanya layanan publik informasi Desa terkait informasi pelatihan las bagi pemuda Desa Aik mual, saya bagian perencanaan dalam Desa Aik Mual ini langsung menyusun perencanaan pelatihan ini karena berdampak baik terhadap masyarakat kami khususnya pemuda Desa kami ini, begitu datang informasi tersebut dari Kepala Desa, langsung saya susun perencanaan pelatihan tersebut agar di utamakan untuk kepentingan kemasylatahan rakyat."

(Wawancara dengan Muhammad Syarifudin, Kamis, 13 Agustus 2020, Pkl. 13.18 WITA)".

Berdasarkan hasil wawancara di atas dalam mengatasi pengangguran, pemerintah desa bergerak cepat untuk mendukung pembangunan masyarakat yang ada di desa tersebut. 
Dengan adanya komunikasi antara pemerintah desa dengan pemuda setempat, kegiatan pelatihan las dapat dilakukan. Pelaksanaan kegiatan tersebut diawali dengan sosialisasi kepada pemuda setempat untuk mendapatkan materi mengenai pelatihan las. Di dalam sosialisasi tersebut, komunikasi yang dilakukan secara dua arah sehingga menimbulkan efek yaitu diskusi antara pemerintah desa selaku penyelenggara dengan pemuda desa yang mendapatkan pelatihan.

Pelaksanaan sosialisasi terjadi sebelum masa work from home diberlakukan oleh pemerintah, sehingga forum diskusi ini mendapatkan antusias dari pemuda desa untuk segera melaksanakan praktik pelatihan. Kegiatan pelatihan ini melalui beberapa tahap, dimana tahap pertama adalah sosialisasi kegiatan oleh pemerintah desa, kemudian tahap kedua adalah kegiatan pelaksanaan, dan tahap berikutnya adalah monitoring pelaksanaan kegiatan. Berikut di bawah ini adalah beberapa dokumentasi kegiatan pelatihan las tersebut.

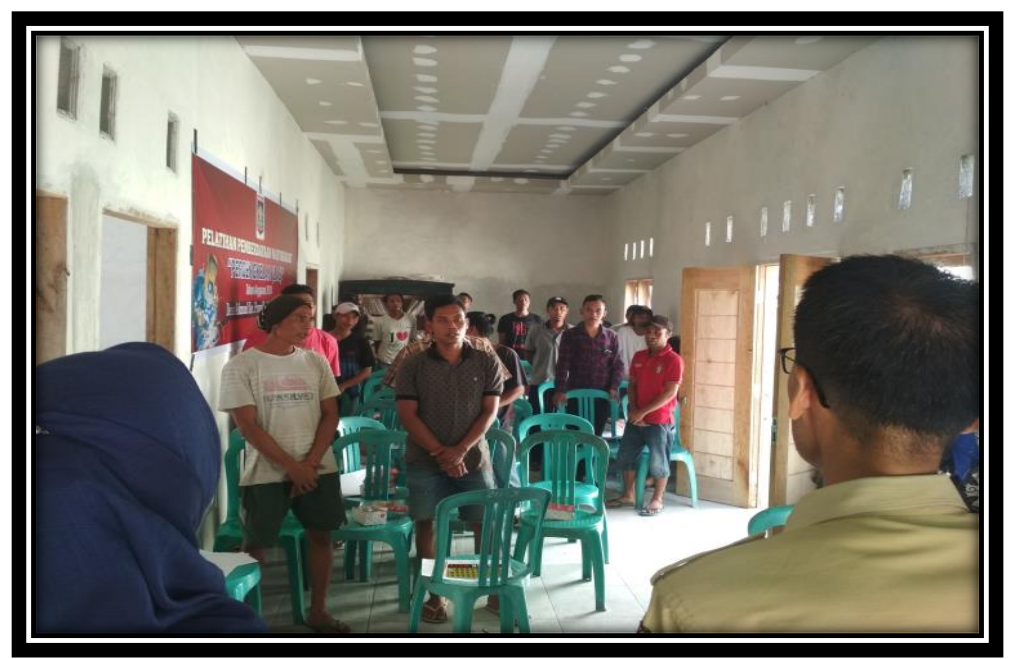

Gambar 1. Sosialisasi Kegiatan Pelatihan Las Di Desa Aikmual Kecamatan Praya Sumber: Dokumentasi Kantor Desa Aikmual Kecamatan Praya 2020

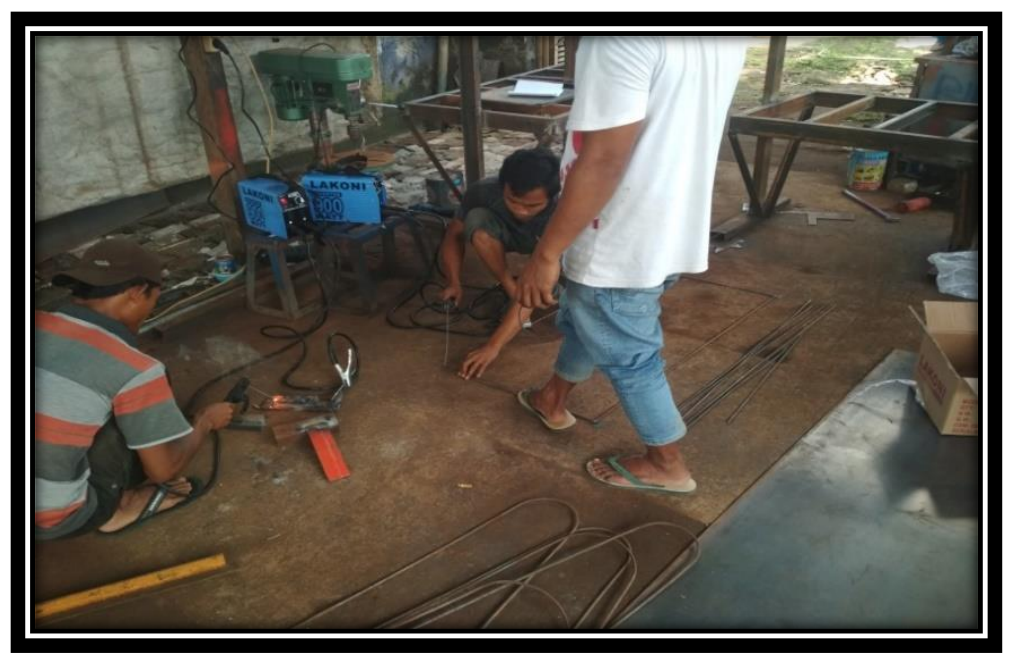

Gambar 2. Pelaksanaan Praktik Las oleh Pemuda Desa Aikmual Kecamatan Praya Sumber: Dokumentasi Kantor Desa Aikmual Kecamatan Praya 2020 


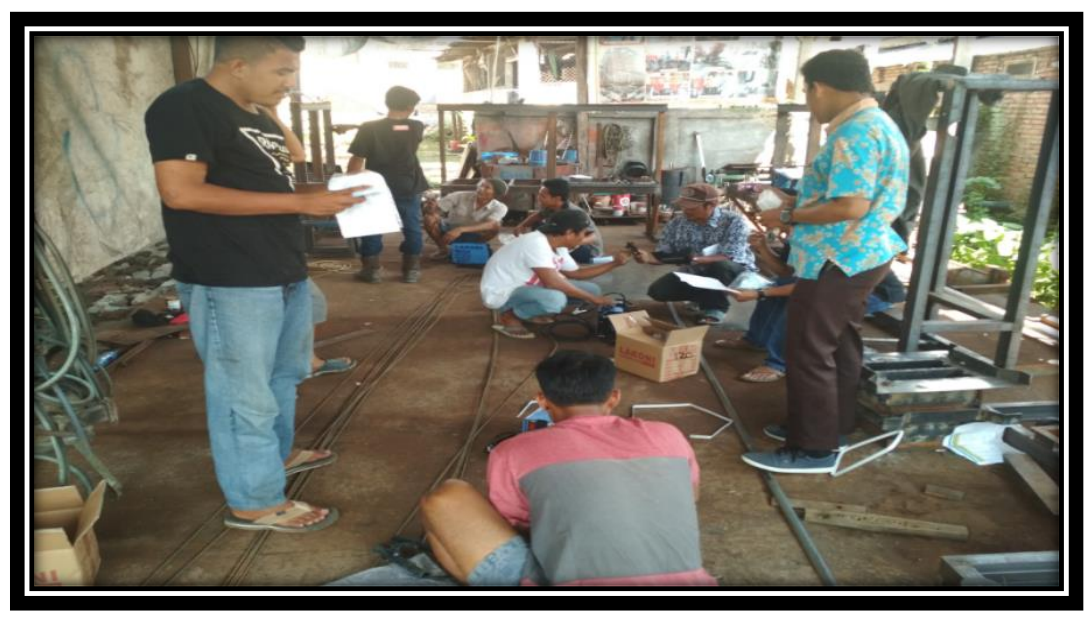

Gambar 3. Monitoring Pelaksanaan Kegiatan Pelatihan Las di Desa Aikmual Kecamatan Praya Sumber: Dokumentasi kantor Desa Aikmual Kecamatan Praya 2020

Peneliti menganalisa dengan dikaitkan dengan teori SUtaryo (2005:279) bahwa Pemerintah Desa Aikmual mencoba untuk membangun kapasitas dari pemudanya untuk meningkatkan kemampuan atau keahlian di bidang las. Oleh karena itu, output dari kegiatan ini menjadi dasar bagi pemuda untuk bisa mengembangkan karir ke depannya. Selain itu pemerintah desa juga secara terbuka dan adil untuk memberi kesempatan kepada pemuda desa agar mengikuti kegiatan yang sudah diprogramkan. Program pelatihan las ini sudah berjalan dari tahun 2019, dimana tahun 2020 merupakan kelanjutan. Kegiatan kenajutan ini perlu pemantauan seperti yang tertera dalam gambar di atas, adanya monitoring untuk bisa dipantau perkembangan kegiatan selama ini.

Pelaksanaan kegiatan di atas jika dianalisa juga dengan teori Jact Rothman merupakan pengembangan masyarakat lokal. Pemerintah desa berusaha untuk memajukan perekonomian masyarakat bukan dalam bentuk barang, melainkan dalam pemberian keahlian atau ketrampilan. Oleh karena itu, dari pelaksanaan kegiatan di atas merupakan tujuan proses yang pemerintah desa coba terapkan kepada pemuda desa tersebut. Proses pembelajaran yang diberikan inilah menjadi bekal bagi pemuda desa untuk mengembangkan karirnya sesuai dengan materi pembelajran pelatihan.

Proses komunikasi pembangunan jika dianalisa berdasarkan Dilla (2007:120) bahwa pelaksanaan kegiatan memang melibatkan tiga komponen, yaitu komunikator, pesan, komunikan, serta dampak yang dihasilkan dari komunikasi pembangunan. Komunikator disini melibatkan pemerintah desa sebagai poros pelaksana untuk bisa menyampaikan materi pembangunan kepada pemuda desa sebagai sasaran kegiatan. Ketika komunikasi ini telah terjadi, kemudian timbul efek, yaitu pemuda desa mengambil peran dalam pelaksanaan kegiatan sebagai peserta. Pelaksanaan kegiatan yang diberikan oleh pemerintah desa mendapatkan respon dari pemuda desa yang telah melakukan atau mengikuti kegiatan tersebut. Respon dari pemuda tersebut seperti tertuang dalam hasil wawancara berikut dengan perwakilan pemuda selaku ketua kelompok, Yayan Suparlan.

“...pelaksanaan program pemberdayaan masyarakat Desa Aik Mual Kecamatan Praya Lombok Tengah ini kepada pemuda pengangguran sudah terlaksana dengan baik. keterampilan sekaligus keahlian yang diberikan 
kepada pemuda pengangguran melalui pembinaan dan sekaligus pelatihan. Adapun materi yang diberikan dalam pembinaan dan pelatihan tersebut seperti pengenalan alat, fungsi alat dan bagaimana menggunakan alat tersebut dengan baik dan benar, bahkan secara langsung memprkatikkan alat dimaksud"

(Hasil Wawancara dengan Yayan Suparlan, Kamis, 13 Agustus 2020, Pkl. 18.19 WITA).

Pelaksanaan komunikasi pembangunan di Desa Aikmual Kecamatan Praya tidak lepas komunikasi yang sinergi antara pemerintah Desa Aikmual dengan pemuda. Aktivitas komunikasi yang dilakukan oleh komunikator (pemerintah desa) dengan komunikan (pemuda desa) dalam proses komunikasi pembangunan berusaha untuk mengatasi angka pengangguran yang ada di Desa Aikmual. Pemerintah desa bukan tempat sebagai penyedia lapangan pekerjaan, melainkan memberikan fasilitas untuk pemuda dalam memberikan ketrampilan atau keahlian yang dapat dimanfaatkan pemdua untuk jangka panjang mereka. Oleh karena itu, Pemerintah Desa berupaya untuk terus melakukan inovasi dalam kegiatan kelanjutan agar masyarakat Desa Aikmual lainnya ikut merasakan setiap program kerja yang ada di desa tersebut.

\section{Simpulan}

Kesimpulan pada penelitian ini dalah komunikasi pembangunan yang dilakukan oleh pemerintah desa fokus pada pengembangan masyarakat lokal dimana proses komunikasi pembangunannya melibatkan aspek komunikator (pemerintah desa), pesan (materi sosialisasi, pelatihan), komunikan (pemuda desa), efek (respon pemuda desa dari pelaksanaan kegiatan). selain itu juga, komunikasi pembangunan yang dilaksanakan Pemerintah Desa Aikmual Kecamatan Praya menerapkan empat aspek, yaitu kapasitas, keadilan, pemberdayaan, serta berkelanjutan.

\section{Daftar Pustaka}

Dilla, S. (2007). Komunikasi Pembangunan Pendekatan Terpadu. Bandung: Simbiosa Rekatama Media.

Effendy, O.U. (2009). Dimensi-dimensi Komunikasi. Bandung : PT Alumni.

Fathurrahman, L. (2016). Pengantar Metodologi Penelitian Ilmu Sosial/IImu Komunikasi. Mataram: FISIPOL Universitas 45 Mataram

Gunadi, T. (2012). Model Inkubator Bisnis Dalam Pendidikan Luar Sekolah Perintisan Pengembangan Desa Agroekowisata Berbasis Pemberdayaan Masyarakat. Prodi PLS: SPS UPI. https://ejournal.upi.edu/index.php/pls/article/viewFile/1024/676

Jay. 10 Agustus 2020.https://radarmandalika.id/pengangguran-di-loteng-diprediksi-melonjak-pemerintah-bisaapa/

Kriyantono, R. (2008). Teknis Praktis Riset Komunikasi. Jakarta: Kencana Prenada Media Grup.

Mahmud, A. (2007). Model Komunikasi Pembangunan Dalam Penyediaan Prasarana Perdesaan Di KAwasan Pesisir Utara Jawa Tengah (Studi Kasus Desa Morodemak dan Purwosari Kabupaten Demak). Semarang: Universitas Diponegoro. https://core.ac.uk/download/pdf/11715395.pdf

Sutaryo. (2005). Sosiologi Komunikasi. Yogyakarta: Arti Bumi. 